\title{
Hepatokines and non-alcoholic fatty liver disease
}

\author{
Dariusz M. Lebensztejn ${ }^{1 凶}$, Marta Flisiak-Jackiewicz' ${ }^{1}$ Irena Białokoz-Kalinowska², \\ Anna Bobrus-Chociej ${ }^{1}$ and Irina Kowalska ${ }^{3}$
}

1Department of Pediatrics, Gastroenterology and Allergology, Medical University of Bialystok, Poland; ${ }^{2}$ Medical Institute, Lomza State University of Applied Sciences, Poland; ${ }^{3}$ Department of Endocrinology, Diabetology and Internal Medicine, Medical University of Bialystok, Poland

\begin{abstract}
Nowadays non-alcoholic fatty liver disease (NAFLD) is becoming the most common chronic liver pathology both in adults and children. NAFLD manifestation ranges from a simple liver steatosis to steatohepatitis (nonalcoholic steatohepatitis - NASH), which may progress to advanced fibrosis, cirrhosis and end-stage liver disease. Due to the coexistence of visceral obesity, insulin resistance and dyslipidemia, NAFLD is considered to be the hepatic manifestation of metabolic syndrome. In recent years, in the pathogenesis of metabolic syndrome, type 2 diabetes mellitus, cardiovascular disease and also NAFLD, more and more attention has been paid to the so-called organokines, proteins with both paracrine or/ and endocrine activities. These include most known adipokines (mainly produced by adipose tissue), myokines (mainly produced by skeletal muscles) and hepatokines exclusively or predominantly produced by the liver. It was shown that the liver may affect the lipids and glucose metabolism by hepatokines released into the blood and NAFLD seems to be associated with altered hepatokines production. Fetuin-A, fibroblast growth factor-21 (FGF-21), selenoprotein $\mathrm{P}$, sex hormone-binding globulin (SHBG), angiopoietin-related growth factor (also known as angiopoietin-related protein 6) and leukocyte derived chemotaxin 2 (LECT2) are considered as the most important hepatokines. In this review, we provide an overview of the main hepatokines and we summarize the association of liver-derived proteins with the development and progression of NAFLD.
\end{abstract}

Key words: non-alcoholic fatty liver disease, fetuin-A, fibroblast growth factor-21, selenoprotein $\mathrm{P}$, sex hormone-binding globulin, angiopoietin-related growth factor, leukocyte derived chemotaxin 2

Received: 19 January, 2016; revised: 10 May, 2016; accepted:

18 May, 2016; available on-line: 6 June, 2016

\section{INTRODUCTION:}

In recent years, more and more attention has been paid to the so-called organokines: proteins presenting both paracrine and/or endocrine activities. The most known and well-examined of them are adipokines: e.g. adiponectin, leptin, resistin, retinol-binding protein 4, visfatin, chemerin, omentine (fat-derived), myokines: e.g. irisin, interleukin 6, brain-derived neurotrophic factor, follistatin-related protein 1 (skeletal muscle-derived) and hepatokines, which are mainly produced by the liver. The latter include fetuin-A, fibroblast growth factor-21 (FGF-21), selenoprotein P, sex hormone-binding globulin (SHBG), angiopoietin-related growth factor (AGF), and leukocyte derived chemotaxin 2 (LECT2) (Parola \&
Mara, 2011; Stefan \& Haring, 2013; Reschke \& Eckel, 2013; Lan et al., 2014).

Nonalcoholic fatty liver disease (NAFLD) is currently the most common chronic liver disorder both in adults and children. This is not a homogeneous disease entity; depending on the severity of the pathological process, it may present as an isolated hepatic steatosis (simple steatosis), nonalcoholic steatohepatitis (NASH), or may lead to liver cirrhosis and hepatocellular carcinoma (HCC) (Caldwell \& Argo, 2010; Vernon et al., 2011; Ertle et al., 2011). In some cases, patients with NAFLD and advanced liver cirrhosis require liver transplantation (Burke et al., 2004; Heuer et al., 2012). Recently, genetic studies demonstrated that single nucleotide polymorphisms (SNPs) in genes involved in lipid metabolism (Lipin 1, patatin-like phospholipase domain containing-3-PNPLA3), oxidative stress (superoxide dismutase 2), insulin signaling (insulin receptor substrate-1), and fibrinogenesis (Kruppel-like factor 6) are associated with a risk for development and progression of NAFLD (Dongiovanni et al., 2013). It should be mentioned that NAFLD related to variation in PNPLA3 gene (SNP rs738409) is not associated with insulin resistance (Romeo et al., 2008; Kantartzis et al., 2009).

NAFLD affects mainly patients with visceral obesity, dyslipidemia, insulin resistance or impaired glucose tolerance. These features are also included in the definition of the metabolic syndrome. Therefore, NAFLD is considered as a specific manifestation of the metabolic syndrome (Targher et al., 2010; Pacifico et al., 2011; Gaudio et al., 2012). It was shown that both disorders are characterized by an increased tendency to develop an earlier atherosclerotic process than in the general population, and the results of the recent studies indicate that NAFLD is an independent factor associated with the progression of atherosclerosis (Targher et al., 2010). In comparison with the general population, the NAFLD patients also exhibited an increased risk of mortality mainly from cardiovascular disease (CVD) (Adams \& Angulo, 2005; Targher et al., 2005).

This paper is the comprehensive review outlining the most recent updates on association of hepatokines with NAFLD.

As it was mentioned above NAFLD affects mainly patients with insulin resistance. There are multiple organs/ tissues involved in the pathogenesis of insulin resistance

\footnotetext{
$\triangle$ e-mail: lebensztejn@hoga.pl
}

Abbreviations: AGF, angiopoietin-related growth factor; FGF-21, fibroblast growth factor - 21; HOMA-IR, homeostasis, model assessment - insulin resistance; MRI, magnetic resonance imaging; NAFLD, non-alcoholic fatty liver disease; NASH, non-alcoholic steatohepatitis; SEPP1, selenoprotein P; SHBG, sex hormone-binding globulin; LECT2, leukocyte derived chemotaxin 2 
Table 1. The characteristics of hepatokines

\begin{tabular}{|c|c|c|c|c|c|}
\hline Hepatokine & $\begin{array}{l}\text { Source of } \\
\text { hepatokine }\end{array}$ & $\begin{array}{l}\text { Targeting } \\
\text { organs }\end{array}$ & Mechanism of actions & Functions & $\begin{array}{l}\text { Serum concentration } \\
\text { in insulin resistant } \\
\text { states }\end{array}$ \\
\hline $\begin{array}{l}\text { Fetuin-A } \\
\text { (Mori et al., 2006; } \\
\text { Stefan et al., 2006; } \\
\text { Dogru et al., 2013) }\end{array}$ & Mainly liver & $\begin{array}{l}\text { Liver, } \\
\text { skeletal mu- } \\
\text { scles }\end{array}$ & $\begin{array}{l}\text { Inhibits autophosphorylation } \\
\text { of insulin receptor in liver and } \\
\text { skeletal muscles } \\
\text { Promotes activation of TLR } \\
4 \text {, which induce inflammatory } \\
\text { signaling, by saturated fatty } \\
\text { acids }\end{array}$ & $\begin{array}{l}\text { Biomarker of } \\
\text { NAFLD, insulin } \\
\text { resistance, cardio- } \\
\text {-vascular risk, neu- } \\
\text { ro-degenerative } \\
\text { disorders, subcli- } \\
\text { nical inflammation }\end{array}$ & Increased \\
\hline $\begin{array}{l}\text { FGF-21 } \\
\text { (Zhang et al., 2015) }\end{array}$ & $\begin{array}{l}\text { Mainly liver, } \\
\text { also adipose } \\
\text { tissue, pancreas }\end{array}$ & $\begin{array}{l}\text { Liver, } \\
\text { Adipose tissue, } \\
\text { Brain, } \\
\text { Kidney }\end{array}$ & $\begin{array}{l}\text { Liver- FGF-21 directly regulates } \\
\text { lipid metabolism and reduces } \\
\text { hepatic lipid accumulation } \\
\text { in an insulin-independent } \\
\text { manner; } \\
\text { Adipose tissue- increases glu- } \\
\text { cose uptake via GLUT1, regula- } \\
\text { tes lipolysis, } \\
\text { induces synthesis and secre- } \\
\text { tion of adiponectin; stimula- } \\
\text { tes uncoupling of protein } 1 \\
\text { (UCP-1) }\end{array}$ & $\begin{array}{l}\text { Biomarker of } \\
\text { NAFLD } \\
\text { Treatment with } \\
\text { recombinant FGF- } \\
21 \text { improves insu- } \\
\text { lin sensitivity }\end{array}$ & Increased \\
\hline $\begin{array}{l}\text { Seleno-protein P } \\
\text { (Choi et al., 2013) }\end{array}$ & Liver & Liver & $\begin{array}{l}\text { Impairs insulin signaling in } \\
\text { hepatocytes }\end{array}$ & $\begin{array}{l}\text { Biomarker of } \\
\text { NAFLD }\end{array}$ & Increased \\
\hline $\begin{array}{l}\text { SHBG } \\
\text { (Simo et al., 2015) }\end{array}$ & Liver & $\begin{array}{l}\text { Targeting } \\
\text { organs for } \\
\text { androgens and } \\
\text { estrogens }\end{array}$ & $\begin{array}{l}\text { Binding of sex steroids (andro- } \\
\text { gens and estrogens) and regu- } \\
\text { lation of their bioavailability }\end{array}$ & $\begin{array}{l}\text { Sex - hormones } \\
\text { transporter } \\
\text { Biomarker of insu- } \\
\text { lin resistance }\end{array}$ & Decreased \\
\hline $\begin{array}{l}\text { AGF } \\
\text { (Kadomatsu et al., } \\
2011 \text { ) }\end{array}$ & Liver & $\begin{array}{l}\text { Liver, } \\
\text { Skeletal mu- } \\
\text { scles, } \\
\text { Endothelial } \\
\text { cells }\end{array}$ & $\begin{array}{l}\text { Regulates lipids, glucose (in- } \\
\text { hibition of gluconeogenesis) } \\
\text { and increases systemic energy } \\
\text { metabolism; induces angio- } \\
\text { genesis and arteriogenesis by } \\
\text { ERK1/2-eNOS-NO pathway in } \\
\text { endothelial cells }\end{array}$ & $\begin{array}{l}\text { Biomarker of obe- } \\
\text { sity, type } 2 \text { diabe- } \\
\text { tes mellitus }\end{array}$ & Increased \\
\hline $\begin{array}{l}\text { LECT2 } \\
\text { (Lan et al., 2014) }\end{array}$ & Liver & $\begin{array}{l}\text { Liver, skeletal } \\
\text { muscles }\end{array}$ & $\begin{array}{l}\text { Impairs insulin signaling in } \\
\text { skeletal muscles }\end{array}$ & $\begin{array}{l}\text { Biomarker of NA- } \\
\text { FLD, obesity??? }\end{array}$ & Increased \\
\hline
\end{tabular}

with the skeletal muscles, adipose tissue and liver playing a significant role.

Liver is a very important organ of glucose metabolism responsible for the glucose storage (hepatic glycogenogenesis) and glucose production (gluconeogenesis). Additionally, liver plays a role in the lipoprotein metabolism. Insulin inhibits glucose release by the liver; it influences the glycogenogenesis, glycogenolysis and gluconeogenesis by controlling the activity of the key enzymes of these processes (Roden, 2006; Stefan et al., 2008).

Epidemiological studies revealed that the NAFLD is connected mostly to the visceral obesity and impaired glucose tolerance and/or type 2 diabetes mellitus. Another important observation is high prevalence of NAFLD in non-obese men from Asia, with polymorphism of apolipoprotein C3 (APOC3), which increases plasma apolipoprotein C3 concentrations. The consequence of this is the inhibition of lipoprotein lipase activity and impaired chylomicrons clearance (Petersen et al., 2010). Moreover, APOC3 mRNA which is increased in fatty liver is regulated by single nucleotide polymorphisms in APOC3 and its influence depends on visceral obesity (Peter et al., 2012). Additionally, NAFLD is a typical finding in lipodystrophic patients. The lipodystrophic syndromes, characterized by the lack of subcutaneous adipose tissue are associated with the marked insulin resistance in the skeletal muscles and the liver, increased plasma triglycerides (TG) concentrations and hepatic steatosis (Oral et al., 2002). These data suggest that the ina- bility of adipose tissue to store lipids in the form of TG results in lipid overflow and ectopic fat accumulation in other organs. This can be caused by an excess of nutrients which leads to obesity with an inflammation in adipose tissue or dysfunctional adipose tissue which is seen in lipodystrophic syndromes. In these situations lipid overflow is crucial for the induction of insulin resistance in the liver. The important question is how intracellular hepatic fat accumulation influences insulin signaling and induces hepatic insulin resistance. An excessive free fatty acids (FFA) flux from the adipose tissue increases the availability of long chain fatty acids to the hepatocytes. The imbalance between fatty acids oxidation and storage in hepatocytes results in the synthesis of the intermediates of lipid metabolism like diacylglycerol (DAG) and ceramides. Data from the experimental studies revealed that lipid infusion results in an increase of DAG content in skeletal muscles in rodents and activation of the theta form of protein kinase C (PKC $\theta)$, so-called DAG-novel protein kinase $\mathrm{C}$ (nPKC). PKCO inhibits insulin signaling by activation of serine phosphorylation in insulin receptor substrate-1 (IRS-1) (Yu et al., 2002)._In experimental model of NAFLD, induced by high-fat diet, the impairment of insulin action was also related to another $\mathrm{nPKC}$ activity - epsilon PKC (PKCE) (Samuel et al., 2004). The data obtained by Kumashiro et al. (2011) in humans confirmed the role of DAG accumulation in the liver and activation of PKC $\varepsilon$ in pathogenesis of hepatic insulin resistance. Moreover, DAG content was the strongest 
predictor of hepatic insulin resistance. Data from the mouse model with the deletion of the gene encoding PKC $\varepsilon$ confirmed the crucial role of this kinase in impairment of insulin action in the liver (Raddatz et al., 2011). Review of the data indicates that accumulation of DAG in hepatocytes and subsequent activation of PKC $\varepsilon$ in the liver are responsible for the hepatic insulin resistance (Perry et al., 2014, Bierkenfeld et al., 2014). It gives the possibility for novel therapeutic approaches to diminish the epidemic of NAFLD.

An impaired insulin signaling in the liver results in increased endogenous glucose production and altered lipoprotein metabolism which leads to hyperglycemia, type 2 diabetes and atherogenic dyslipidemia. However, it is claimed that glucose and lipid metabolism might be also influenced by the liver-derived proteins (Bierkenfeld et al., 2014).

\section{FETUIN-A}

Fetuin-A, also known as alpha-2-Heremans-Schmid glycoprotein $(64 \mathrm{kDa})$, is produced mainly in the liver. The placenta and also tongue are mentioned as minor sources of this hepatokine (Denecke et al., 2003). This glycoprotein was discovered in 1944 in bovine calves (Pedersen, 1944). In humans, fetuin-A gene is located on chromosome 3q27, which was identified as susceptibility locus for type 2 diabetes and metabolic syndrome (Siddiq et al., 2005). This multipotential glycoprotein is involved in the regulation of bone metabolism, migration of keratinocytes, and control of proteolytic activity. It is also considered as a biomarker for neurodegenerative diseases as well as indicator of insulin resistance, cardiovascular risk, endothelial dysfunction and subclinical atherosclerosis (Stefan et al., 2006; Roos et al., 2010; Mori et al., 2011; Mori et al., 2012; Dogru et al., 2013).

There is a suggestion that fetuin-A constitutes a link between obesity, insulin resistance and NAFLD (Mori et al., 2006; Stefan et al., 2006; Dogru et al., 2013). FetuinA was shown to be an inhibitor of insulin receptor tyrosine kinase in the liver and skeletal muscles, causing inhibition of the autophosphorylation of tyrosine kinase in insulin receptor and insulin receptor substrate 1 (IRS1) which leads to insulin resistance in rodents (Auberger et al., 1989). This observation was also confirmed in humans (Srinivas et al., 1993; Mori et al., 2011). Several years later, further studies showed that mice lacking Absg gene, which encodes fetuin-A, had improved signaling of insulin (Mathews et al., 2002). This finding suggested that this hepatokine might play a crucial role in regulation of insulin sensitivity._It was also shown that fetuin-A plays an important role in lipid-induced insulin resistance in mice (Pal et al., 2012) as well as in humans (Stefan \& Haring, 2013; Stefan et al., 2014). The high concentration of saturated fatty acids (via NF-kB activation) and increased blood glucose (via ERK 1 or 2 signaling pathways activation) induce the hepatic synthesis of this hepatokine (Takata et al., 2009; Dasgupta et al., 2010). Hepatocytes secrete fetuin-A into the blood and the protein binds the insulin receptor in tissues, inhibiting insulin signaling and therefore inducing insulin resistance. In addition, this protein acts as an adapter for saturated fatty acids which by activating Toll-like receptors (TLR) 4 induce inflammatory signaling and insulin resistance (Pal et al., 2012; Heinrichsdorff et al., 2012).

Many authors (Stefan et al., 2006; Reinekr et al., 2008; Haukeland et al., 2012) found an association of fetuin$\mathrm{A}$ and fat accumulation in the liver measured in pro- ton magnetic resonance spectroscopy in obese adults. It therefore appears that the increase in the production of fetuin-A in patients with hepatic steatosis is closely associated with ectopic fat accumulation in the liver, which is observed in NAFLD.

A number of publications demonstrated significantly higher serum fetuin A concentration in a population of adults with morphologically confirmed NAFLD (Yilmaz et al., 2010; Haukeland et al., 2012; Dogru et al., 2013) and also in children (Reinehr et al., 2008; Lebensztejn et al., 2014) compared to the control group.

In our study (Lebensztejn et al., 2014) the correlation of this glycoprotein with HOMA-IR and lipid profile parameters in patients with NAFLD was not confirmed. Haukeland et al. (2012), like in the above-mentioned analysis, did not find any relationship of this biomarker with insulin resistance (HOMA-IR) and lipid metabolism. However, they confirmed the correlation of hepatic expression of fetuin-A with carbohydrate and lipid metabolism key enzymes (SREBP1c, CPT1, PEPCK1, Glu-6-P) but there was no correlation of serum fetuinA with mRNA of this glycoprotein in the liver, which may explain the lack of correlation in serum. In other study (Ou et al., 2012), positive fetuin-A correlations with HOMA-IR and serum triglycerides concentrations were described. In humans, in the study by Stefan et al. (2006) the negative correlation between plasma fetuin A and insulin sensitivity assessed by the euglycemic clamp technique was observed. Importantly, plasma fetuin A concentration was also related to the fat accumulation in the liver, thus suggesting that this protein can serve as a potential link between fatty liver and insulin resistance. Accordingly, the strong relationship between plasma fetuin $A$ and insulin resistance (Matsuda index) in patients with NAFLD was reported (Stefan et al., 2014). Additionally, fetuin A was claimed to be a predictor of type 2 diabetes in humans (Stefan et al., 2014).

Divergent results were observed regarding fetuin-A associations with the severity of liver fibrosis. Yilmaz et al. (2010) showed a positive correlation of this hepatokine and fibrosis score in patients with NAFLD, Sato et al. (2015) confirmed the fetuin-A negative correlation with NAFLD fibrosis score, whereas others did not confirm the association of fetuin-A with the result of the morphological study of liver bioptates (Haukeland et al., 2012; Dogru et al., 2013; Kahraman et al., 2013; Rametta et al., 2014). It was demonstrated that fetuin-A mRNA expression was higher in NASH compared to patients with simple fatty liver (Kahraman et al., 2013). Moreover, the administration of metformin in patients with NAFLD (randomized placebo control trial), although did not cause histological improvement (Haukeland et al., 2009), resulted in the reduction of the serum concentration of fetuin-A (Haukeland et al., 2012). Similarly, the reduction of body weight in obese NAFLD patients leading to a reduction in hepatic fat content resulted in lowering its serum concentration (Reinehr et al., 2008). It was also shown that even short-term, 7-day lasting physical exercise, brought a positive response in lowering the serum concentration of this hepatokine despite the fact, that there was no effect on body weight or hepatic triglyceride content in proton MRI (Malin et al., 2013).

Although it was demonstrated in the general population that fetuin-A is associated with an increased risk of myocardial infarction and ischemic stroke independently of standard risk factors (Weikert et al., 2008); it has not yet been resolved, whether fetuin-A may be considered as a valuable marker of cardiovascular risk in patients with NAFLD. Only Dogru et al. (2013) showed a posi- 
tive correlation between fetuin-A and carotid intima media thickness (cIMT) in adults with NAFLD and markers of serum endothelial dysfunction. The opposite results were obtained by Sato et al. (2015); they found a negative correlation of fetuin-A with average IMT values. Our study found that there was no correlation between hepatokine concentration and any atherosclerotic endothelial changes assessed by measuring IMT, which is a widely recognized marker of early biophysical atherosclerotic process. Additionally, no significant difference in the IMT of children with NAFLD compared to nonNAFLD children was observed (Lebensztejn et al., 2014). Probably, longer exposure to the disease in children is necessary to determine significant differences in IMT value. Yoo et al. (2015) suggested that a very probable mechanism wherein the fetuin-A may cause atherosclerosis is the induction of insulin resistance and inflammatory processes by an increased expression of cytokines on monocytes.

\section{FIBROBLAST GROWTH FACTOR-21}

FGF-21 is a 209 amino acid peptide produced mainly in the liver, but the expression of this protein in the lower extent was also found in the pancreas, testes, duodenum and adipose tissue; gene for FGF-21 is localized on chromosome 19 (Nishimura et al., 2000; Fon Tacer et al., 2010; Li et al., 2013). It is a hepatokine which regulates lipid and carbohydrate metabolism and it was demonstrated that it may play a significant role in the pathogenesis of NAFLD (Liu et al., 2015). FGF-21 directly regulates lipid metabolism and reduces hepatic lipid accumulation in an insulin-independent manner (Zhang et al., 2011; Li et al., 2012; Lee et al., 2014). It affects selected elements of the "multi-hits theory", such as oxidative stress, endoplasmic reticulum stress, mitochondrial dysfunction, and low-grade chronic inflammation $(\mathrm{Ni}-$ shimura et al., 2000; Jiang et al., 2014; Fisher et al., 2014; Kim et al., 2015).

A number of publications showed significantly higher serum concentrations of FGF-21 in a population of patients with NAFLD compared to the controls. It should be emphasized that NAFLD was diagnosed on the basis of different diagnostic criteria (ultrasound, MRI and liver biopsy) ( Li et al., 2010; Yilmaz et al., 2010; Reinehr et al., 2012; Giannini et al., 2013). In our preliminary study serum FGF-21 level was significantly higher in children with NAFLD (diagnosed in ultrasound and ${ }^{1} \mathrm{HMRS}$ ) compared to the controls and to the non-hepatopathic obese patients (Lebensztejn et al., 2016). Only Alisi et al. (2013) in the group of children with biopsy-proven NAFLD showed significantly lower serum concentrations of FGF-21 compared to the controls.

In the studies conducted on patients with NAFLD, it was confirmed that circulating FGF-21 was significantly positively correlated with the hepatic fat content assessed in proton magnetic resonance spectroscopy (Yan et al., 2011), MRI (HFF\%) (Giannini et al., 2013); moreover, the correlation of this peptide with intrahepatic triglycerides assessed in liver biopsy was also confirmed ( $\mathrm{Li}$ et al., 2010).

It was also shown that hepatic FGF-21 mRNA was significantly elevated in NAFLD patients and it correlated with serum levels of this hepatokine (Li et al., 2010; Dushay et al., 2010); in addition it also correlated positively with the degree of liver steatosis (Li et al., 2010). However, Yan et al. (2011) demonstrated lower concentrations of FGF-21 in the patients with severe steatosis measured in ${ }^{1}$ HMRS. The study of Li et al. (2013) suggested that high level of serum FGF-21 may be considered to be an independent predictor of NAFLD. Moreover, Jiang et al. (2014) confirmed that the single nucleotide polymorphism rs499765 is associated with FGF-21 and NAFLD in non-diabetic population.

There is some data regarding the association of FGF-21 and the stages of the severity of liver fibrosis. In the animal model, studies demonstrated that FGF-21 is induced in response to toxic lipid accumulation in the early stage of methionine- and choline-deficient NASH (Tanaka et al., 2015). In pediatric population, Alisi et al. (2013) found a strong inverse correlation between FGF-21 circulating level and NAFLD severity (fibrosis). This data was supported by animal studies which showed that tumor necrosis factor alpha and NFE2 (oxidative stress-activated transcription factors) may impair FGF21 transcription and release (Chartoumekis et al., 2011; Diaz-Delfin et al., 2012). It was also shown that FGF-21 could be regarded as a non-invasive biomarker useful in differentiation of simple fatty liver and NASH. Shen et al. (2012) showed that the total rating of cytokeratin-18 and FGF-21 may be used in non-invasive diagnosis of NASH.

It is suggested that the increase in the hepatic expression of FGF-21 is a response to FGF-21 resistance, and just FGF-21 resistance may be involved in the pathogenesis of NAFLD/NASH. The increase of FGF-21 level may be a potential protective factor against lipid and carbohydrate metabolism disorders (Hui et al., 2013; Liu et al., 2015). In diet-induced obese mice, administration of FGF-21 caused a decrease in hepatic steatosis, reduced levels of triglycerides in serum and liver, and reversible fatty liver by inhibition of SREBP-1, a key transcription factor of lipogenesis (Badman et al., 2007; Xu et al., 2009).

In addition to the reversibility of hepatic steatosis, intravenous administration of FGF-21 improved insulin sensitivity and decreased fasting glucose in animal models of NAFLD (Coskun et al., 2008; Xu et al., 2009). It was also shown that adenovirus-mediated knockdown of hepatic FGF-21 leads to the development of hepatic steatosis and dyslipidemia due to impaired expression of genes involved in lipid metabolism in the liver (Hui et al., 2013). Fisher et al. (2014) conducted a study of FGF-21-knockout mice, stating that in the absence of FGF-21, accumulation of inactivated fatty acids results in lipotoxic damage and increased steatosis. It was demonstrated by studying OLEFT rats that lifestyle modification (chronic exercise and caloric restriction) reduces hepatic expression of FGF-21 mRNA and circulating FGF-21 concentrations, which may indicate that such therapy alleviate FGF-21 resistance (Fletcher et al., 2012).

At present, FGF-21 is considered a novel metabolic regulator, which is involved in the pathogenesis of NAFLD. Thus, it seems that it could be used in the treatment of NAFLD/NASH. Subcutaneously administered short-acting FGF-21 analog (LY2405319) improved insulin sensitivity and lipid profile in $a b / o b$ and diet-induced obese mice (Kharitonenkov et al., 2013). Gaich et al. (2013) analyzed the effect of LY2405319 in a randomized, placebo controlled trial in a small group of obese patients with type 2 diabetes. They found the significant improvements in dyslipidemia and favorable effect on body weight, fasting insulin and adiponectin level. Mu et al. (2012) using pegylated human FGF-21 analog twice-weekly observed reduced blood glucose, plasma lipids, liver triglycerides, and plasma glucagon and enhanced pancreatic insulin content, islet num- 
ber, and glucose-dependent insulin secretion in rodents $(d b / d b$ mice). Further studies are needed to confirm the efficacy of this therapy in humans with NAFLD.

\section{SELENOPROTEIN P}

Selenoprotein P (SEPP1) is a $60 \mathrm{kDa}$ glycoprotein produced primarily in the liver; it is considered a seleniumcarrier protein transporting it to tissues such as the testes and brain (Burk \& Hill, 2005). Human selenoprotein P gene was mapped to $5 \mathrm{q} 31$ (Hill et al., 1996). In patients diagnosed with type 2 diabetes, it was shown that serum concentrations of this hepatokine positively correlated with the insulin hepatic overproduction of selenoproteins P causing insulin resistance (Misu et al., 2010). Similarly, a positive correlation with the parameters associated with cardiovascular risk factors (circumference waist, hsCRP, triglycerides level, carotid intima media thickness) as well as aspartate aminotransferase activity was noted (Yang et al., 2011). An inverse correlation of selenoproteins $P$ level with the adiponectin was also observed (Misu et al., 2012).

In NAFLD patients with visceral obesity, higher concentration of selenoprotein $\mathrm{P}$ were observed compared to the control group. In addition, patients in the highest selenoprotein P tertile showed a 7.5 times greater risk of NAFLD than those in the lowest tertile. Moreover, the correlation between serum selenoprotein P and LAI (liver attenuation index) assessed by computed tomography was also found, which can be considered as semi-quantitative indicator of hepatic fat accumulation. Therefore, this hepatokine may be regarded as a novel biomarker of NAFLD (Choi et al., 2013). In patients with type 2 diabetes and the patients with NAFLD alike, there was the correlation of selenoprotein $\mathrm{P}$ with cardiovascular risk factors, i.e. subclinical parameters of inflammation and arterial stiffness (Choi et al., 2013).

Misu et al. (2010) demonstrated that administration of selenoprotein P impaired insulin signaling in hepatocytes and selenoprotein $\mathrm{P}$ deficiency in mice leads to an improvement in insulin sensitivity due to inactivation of adenosine monophosphate-activated protein kinase. Therefore, they suggested that selenoprotein $\mathrm{P}$ may be the target for the treatment of insulin resistance-associated diseases. However, further experimental and clinical studies are necessary to confirm this hypothesis.

\section{SEX HORMONE-BINDING GLOBULIN}

Sex hormone-binding globulin (SHBG) is produced mainly in the liver (Khan et al., 1981). The gene coding human SHBG is localized in the p12-p13 region on the short arm of chromosome 17 (Berube et al., 1990). The main function of this hepatokine is the sex hormone transport, however, SHBG circulating concentration is also associated with glucose metabolism, adiposity and metabolic syndrome components (Sutton-Tyrrell et al., 2005; Peter et al., 2010; Lazo et al., 2015).

In postmenopausal women with biopsy-proven NAFLD (Polyzos et al., 2013), there was lower concentration of this hepatokine detected compared to the control group and it was found that the serum concentration of SHBG was associated with NAFLD regardless of age, BMI and waist circumference. Similarly, the association of low concentration of this hepatokine with NAFLD was also demonstrated in type 2 diabetic patients (Hua et al., 2014).
In addition, it was also shown that serum concentrations of SHBG decreased with an increase of intrahepatic fat content and that introduction of lifestyle modification as a therapy for obesity caused an increase in circulating concentration of SHBG, which was associated with a decrease of liver fat content (Stefan et al., 2009). An analogous relationship between SHBG and intrahepatic fat content was confirmed in different groups of patients where liver steatosis was assessed using ultrasound (Shin et al., 2011; Fletcher-Mors et al., 2014), MRI (Bonnet et al., 2013) or computed tomography (Kavanagh et al., 2013; Lazo et al., 2015).

Recently, it was found that the production of SHBG is regulated by adiponectin. Simo et al. (2014) showed that adiponectin increases SHBG production by the activation of AMPK leading to a reduction in hepatic lipid content. Peter et al. (2010) demonstrated that circulating SHBG concentration was closely associated with hepatic insulin sensitivity independently of adiponectin and fetuin-A.

So far, the only one study regarding the simultaneous evaluation of several hepatokines in the group of men with the disturbances of glucose and lipid metabolism did not confirm an association between SHBG and neither fetuin-A nor FGF-21 concentrations (Bonnet et al., 2013).

\section{ANGIOPOIETIN-RELATED GROWTH FACTOR}

Angiopoietin-related growth factor (AGF) (also known as angiopoietin-related protein 6) encoded by the gene Angtl6, secreted into the circulation predominantly from the liver, was identified by Oike et al. (2003). They also found that AGF-deficient mice developed obesity, insulin resistance and lipid accumulation in liver and skeletal muscle, and hepatic overexpression of AGF by adenoviral transduction was also connected with an increased level of circulating AGF. Therefore this hepatokine might have an important function in lipid and carbohydrate metabolism and might be regarded as a protein that antagonizes obesity and insulin resistance (Oike et al., 2005). However, Ebert et al. (2009) showed that serum AGF concentration is significantly increased in diabetic compared with non-diabetic patients. In the further study conducted by these authors, in a large, well- metabolically characterized cohort (Ebert et al., 2014), patients with type 2 diabetes had significantly higher serum AGF concentration in comparison to controls. In addition, AGF positively correlated with insulin resistance markers and negatively with HDL-cholesterol. Namkung et al. (2011) showed higher levels of AGF in patients with metabolic syndrome compared to the controls and the metabolic syndrome was a predictor of serum AGF level. Therefore, it was demonstrated, that the results for AGF concentrations in humans are different than those obtained in an experimental model. Namkung et al. (2011) suggested that the function of AGF may be different in humans than in animals. The patients with metabolic syndrome or type 2 diabetes may present decreased sensitivity to AGF (AGF resistance). Kitazawa et al. (2007) proposed a theory that the mechanism through which the AGF affects the glucose metabolism is due to the fact that the AGF suppresses glucose production in hepatocytes in a concentration-dependent manner by reduced expression of glucose-6-phosphatase at both transcriptional and translational levels. In addition, phosphatidylinositol 3-kinase- and protein kinase B-dependent nuclear export of forkhead box class O1 appears 
to mediate this effect. So far, there are no publications on the role of the AGF in NAFLD available but the abovementioned data suggest that this hepatokine might potentially be involved in the pathogenesis of this disease. In addition, in vitro assays showed reduced hepatic gluconeogenesis after treatment with AGF (Kitazawa et al., 2007), suggesting that AGF can be considered as a novel therapeutic target of diabetes, obesity, metabolic syndrome as well as NAFLD.

\section{LEUKOCYTE DERIVED CHEMOTAXIN 2}

Recently, a novel hepatokine, leukocyte derived chemotaxin 2 (LECT2), linking obesity with muscle insulin resistance was discovered (Lan et al., 2014). Firstly, LECT2 was identified as a novel neutrophil chemotactic protein (Yamagoe et al., 1996). In humans LECT2 is mainly expressed in hepatocytes (Yamogoe S et al., 1998). Data from animal studies pointed out that LECT2 expression in the liver is higher after high-fat diet. The mice knockout for LECT2 exhibited improved insulin sensitivity in skeletal muscles thus suggesting LECT2 role in metabolic disorders. The treatment with recombinant LECT2 protein induced insulin resistance in skeletal muscles by impairing insulin signaling (Lan et al., 2014). In experimental studies, Lect2 expression in the liver was negatively regulated by energy-depletion sensing AMP kinase. Moreover, in human study serum LECT2 correlated positively with BMI, waist circumference, HOMA-IR and HbA1c (Lan et al., 2014). Okumura et al. (2013) reported that serum LECT2 level was significantly higher in patients with obesity and NAFLD.

\section{SUMMARY}

The obesity epidemic has also led to the changes in the epidemiology of liver diseases. At present, NAFLD is the most common liver disorder. The pathogenesis of this disease is complex and has not been fully elucidated yet. The experimental and human studies point out the role of the exclusively or predominantly liver-derived hepatokines. It was shown that the liver may affect the metabolism of lipids and glucose by the hepatokines release into the blood and NAFLD seems to be associated with their altered production. Moreover, it appears that hepatokines may be regarded as biomarkers of an ectopic fat accumulation in the liver and markers of the disease progression. It was suggested that some of them may be the target for prevention and treatment of insulin resistance-associated diseases also including NAFLD. However, further experimental and clinical studies are necessary to confirm these hypotheses.

\section{Acknowledgements}

This study was financially supported by a grant from the Medical University of Bialystok, Poland No: N/ST/ ZB/15/002/1143; 153-43771L.

\section{REFERENCES}

Adams LA, Angulo P (2005) Recent concepts in non-alcoholic fatty liver disease. Diabet Med 22: 1129-1133. http://dx.doi.org/10.1111/ j.1464-5491.2005.01748.x.

Alisi A, Ceccarelli S, Panera N, Prono F, Petrini S, De Stefanis C, Pezzullo M, Tozzi A, Villani A, Bedogni G, Nobili V (2013) Association between serum atypical fibroblast growth factors 21 and 19 and pediatric nonalcoholic fatty liver disease. PLoS One 8: e67160. http://dx.doi.org/10.1371/journal.pone.0067160.
Auberger P, Falquerho L, Contreres JO, Pages G, Le Cam G, Rossi B, Le Cam A (1989) Characterization of a natural inhibitor of the insulin receptor tyrosine kinase: cDNA cloning, purification, and anti-mitogenic activity. Cell 58: 631-640. http://dx.doi. org/10.1016/0092-8674(89)90098-6.

Badman MK, Pissios P, Kennedy AR, Koukos G, Flier JS, MaratosFlier E (2007) Hepatic fibroblast growth factor 21 is regulated by PPAR alpha and is a key mediator of hepatic lipid metabolism in ketotic states. Cell Metab 5: 426-437. http://dx.doi.org/10.1016/j. cmet.2007.05.002.

Berube D, Seralini GE, Gagne R, Hammond GL (1990) Localisation of the human sex hormone-binding globulin gene (SHGB) to the short arm of chromosome 17 (17p12-13). Cytogenet Cell Genet 54: 65-67.

Birkenfeld AL, Shulman GI (2014) Nonalcoholic fatty liver disease, hepatic insulin resistance, and type 2 diabetes. Hepatology 59: 713-723. http://dx.doi.org/10.1002/hep.26672.

Bonnet F, Valayoudom Cephise FL, Gautier A, Dubois S, Massart C, Camara A, Larifla L, Balkau B, Ducluzeau PH (2013) Role of sex steroids, intrahepatic fat and liver enzymes in the association between SHBG and metabolic features. Clin Endocrinol (Oxf) 79: 517522. http://dx.doi.org/10.1111/cen.12089.

Burk RF, Hill KE (2005) Selenoprotein P: an extracellular protein with unique physical characteristic and a role in selenium homeostasis. Annu Rev Nutr 25: 215-235. http://dx.doi.org/10.1146/annurev. nutr.24.012003.132120.

Burke A, Lucey MR (2004) Non-alcoholic fatty liver disease, non-alcoholic steatohepatitis and orthotopic liver transplantation. Am J Transplant 4: 686-693. http://dx.doi.org/10.1111/j.16006143.2004.00432.x

Caldwell S, Argo C (2010) The natural history of non-alcoholic fatty liver disease. Dig Dis 28: 162-168. http://dx.doi. org/10.1159/000282081.

Chartoumekis DV, Ziros PG, Psyrogiannis AI, Papavassiliou AG, Kyriazopoulou VE, Sykiotis GP, Habeos IG (2011) Nrf2 represses FGF21 during long-term high-fat diet-induced obesity in mice. Diabetes 60: 2465-2473. http://dx.doi.org/10.2337/db11-0112.

Choi HY, Hwang SY, Lee CH, Hong HC, Yang SJ, Yoo HJ, Seo JA, Kim SG, Kim NH, Baik SH, Choi DS, Choi K (2013) Increased selenoprotein $\mathrm{P}$ levels in subjects with visceral obesity and nonalcoholic fatty liver disease. Diabetes Metab J 37: 63-71. http://dx.doi. org/10.4093/dmj.2013.37.1.63.

Coskun T, Bina HA, Schneider MA, Dunbar JD, Hu CC, Chen Y, Moller DE, Kharitonenkov A (2008) Fibroblast growth factor 21 corrects obesity in mice. Endocrinology 149: 6018-6027. http://dx.doi. org/10.1210/en.2008-0816.

Dasgupta S, Bhattacharya S, Biswas A, Majumdar SS, Mukhopadhyay S, Ray S, Bhatta-Charya S (2010) NF-kB mediates lipid-induced fetuin-A expression in hepatocytes that impaires adipocyte function effecting insulin resistance. Biochem J 429: 451-462. http://dx.doi. org/10.1042/BJ20100330.

Denecke B, Graber S, Schafer C, Heiss A, Woltje M, Jahnen-Dechent W (2003) Tissue distribution and activity testing suggest a similar but not identical function of fetuin-B and fetuin-A. Biochem $J$ 376: 135-145. http://dx.doi.org/10.1042/BJ20030676.

Diaz-Delfin J, Hondares E, Iglesias R, Giralt M, Caelles C, Villarrova F (2012) TNF- $\alpha$ represses $\beta$-Klotho expression and impairs FGF21 action in adipose cells: involvement of JNK1 in the FGF21 pathway. Endocrinology 153: 4238-4245. http://dx.doi.org/10.1210/ en.2012-1193.

Dogru T, Genc H, Tapan S, Aslan F, Ercin CN, Ors F, Kara M, Sertoglu E, Karslioglu Y, Bagci S, Kurt I, Sonmez A (2013) Plasma fetuin $\mathrm{A}$ is associated with endothelial dysfunction and subclinical atherosclerosis in subjects with nonalcoholic fatty liver disease. Clin Endocrinol (Oxf) 78: 712-717. http://dx.doi.org/10.1111/j.13652265.2012.04460.x.

Dongiovanni P, Anstee QM, Valenti L (2013) Genetic predisposition in NAFLD and NASH: impact on severity of liver disease and response to treatment. Curr Pharm Des 19: 5219-5238. http://dx.doi. org/10.2174/13816128113199990381.

Dushay J, Chui PC, Gopalakrishnan GS, Varela-Rey M, Crawley M, Fisher FM, Badman MK, Martinez-Chantar ML, Maratos-Flier E (2010) Increased fibroblast growth factor 21 in obesity and nonalcoholic fatty liver disease. Gastroenterology 139: 456-463. http://dx.doi. org/10.1053/j.gastro.2010.04.054.

Ebert T, Bachmann A, Losser U, Kratzsch J, Bluher M, Stumvoll M, Fasshauer M (2009) Serum levels of angiopoietin-relatef growth factor in diabetes mellitus and chronic hemodialysis. Metabolism 58: 547-551. http://dx.doi.org/10.1016/j.metabol.2008.11.016.

Ebert T, Kralish S, Loessner U, Jessnitzer B, Stumvoll M, Fasshauer N, Tonjes A (2014) Relationship between serum levels of angiopoietin-related growth factor and metabolic risk factors. Horm Metab Res 46: 685-690. http://dx.doi.org/10.1055/s-0034-1382078.

Ertle J, Dechene A, Sowa JP, Penndorf V, Herzer K, Kaiser G, Schlaak JF, Gerken G, Syn WK, Canbay A (2011) Non-alcoholic fatty liver disease progresses to hepatocellular carcinoma in the ab- 
sence of apparent cirrhosis. Int I Cancer 128: 2436-2443. http://dx. doi.org/10.1002/ijc.25797.

Fisher FM, Chui PC, Nasser IA, Popov Y, Cunniff JC, Lundasen T, Kharitonenkov A, Schuppan D, Flier JS, Maratos-Flier E (2014) Fibroblast growth factor 21 limits lipotoxicity by promoting hepatic fatty acid activation in mice on methionine and choline-deficient diets. Gastroenterology 147: 1073-1083. http://dx.doi.org/10.1053/j. gastro.2014.07.044.

Fletcher JA, Meers GM, Laughlin GM, Ibdah JA, Thyfault JP, Rector RS (2012) Modulating fibroblast growth factor 21 in hyperphagic OLATF rats with daily exercise and caloric restriction. Appl Physiol Nutr Metab 37: 1054-1062. http://dx.doi.org/10.1139/h2012-091.

Fletcher-Mors M, Schick A, Oeztuerk S, Haenle MM, Wilhelm M, Koenig W, Inhof A, Boehm BO, Graeter T, Mason RA, Kratzer W, Akinli AS, EMIL-Study Group (2014) Associations of fatty liver disease and other factors affecting serum SHBG concentrations: a population based study on 1657 subjects. Horm Metab Res 46: 287293. http://dx.doi.org/10.1055/s-0033-1354369.

Fon Tacer K, Bookout AL, Ding X, Kurosu H, John GB, Wang L, Goetz R, Mohammadi M, Kuroo M, Mangelsdorl DJ, Kliwer SA (2010) Research resource: comprehensive expression atlas of the fibroblast growth factor system in adult mouse. Mol Endocrinol 24: 2050-2064. http://dx.doi.org/10.1210/me.2010-0142.

Gaich G, Chien JY, Fu H, Glass LC, Deeg MA, Holland WL, Kharitonenkov A, Bumol T, Schilske HK, Moller DE (2013) The effects of LY2405319, an FGF21 analog, in obese human subjects with type 2 diabetes. Cell Metab 18: 333-340. http://dx.doi.org/10.1016/j. cmet.2013.08.005.

Gaudio E, Nobili V, Franchitto A, Onori P, Carpino G (2012) Nonalcoholic fatty liver disease and atherosclerosis. Intern Emerg Med 7(suppl 3): 297-305. http://dx.doi.org/10.1007/s11739-012-0826-5.

Giannini C, Feldstein AE, Santoro N, Kim G, Kursawe R, Pierpont B, Caprio S (2013) Circulating levels of FGF-21 in obese youth: associations with liver fat content and markers of liver damage. $J$ Clin Endocrinol Metab 98: 2993-3000. http://dx.doi.org/10.1210/ jc.2013-1250.

Haukeland JW, Dahl TB, Yndestad A, Gladhaug IP, Loberg EM, Haaland T, Konopski Z, Wium C, Aasheim ET, Johansen OE, Aukrust P, Halvorsen B, Birkeland KI (2012) Fetuin A in nonalcoholic fatty liver disease: in vivo and in vitro studies. Eur J Endocrinol 166: 503510. http://dx.doi.org/10.1530/EJE-11-0864.

Haukeland JW, Konopski Z, Eggesbo HB, von Volkmann HL, Raschpichler G, Bjoro K, Haaland T, Loberg EM, Birkeland K (2009) Metformin in patients with non-alcoholic fatty liver disease: a randomized, controlled trial. Scand J Gastroenterol 44: 853-860. http:// dx.doi.org/10.1080/00365520902845268.

Heinrichsdorff J, Olessky JM (2012) Fetuin-A: the missing link in lipid-induced inflammation. Nat Med 18: 1182-1183. http://dx.doi. org/10.1038/nm.2869.

Heuer M, Kaiser GM, Kahraman A, Banysch M, Saner FH, Mathe Z, Gerken G, Paul A, Canbay A, Treckmann JW (2012) Liver transplantation in nonalcoholic steatohepatitis is associated with high mortality and post-transplant complications: a single-center experience. Digestion 86: 107-113. http://dx.doi.org/10.1159/000339344.

Hill KE, Dasouki M, Philips JA 3rd, Burk RF (1996) Human selenoprotein P gene maps to $5 \mathrm{q} 31$. Genomics 36 : 550-551. http://dx.doi. org/10.1006/geno.1996.0505.

Hua X, Sun Y, Zhong Y, Feng W, Huang H, Wang W, Zhang T, Hu $Y$ (2014) Low serum sex hormone-binding globulin is associated with nonalcoholic fatty liver disease in type 2 diabetic patients. Clin Endocrinol (Oxf) 80: 877-883. http://dx.doi.org/10.1111/cen.12360.

Hui E, Xu A, Yang HB, Lam KSL (2013) Obesity as the common soil of non-alcoholic fatty liver disease and diabetes: role of adipokines. J Diabetes Investig 4: 413-425. http://dx.doi.org/10.1111/ jdi.12093.

Jiang S, Yan C, Fang QC, Shao ML, Zhang YL, Liu Y, Deng YP, Shan B, Liu JQ, Li HT, Yang L, Zhou J, Dai Z, Liu Y, Jia WP (2014) Fibroblast growth factor 21 is regulated by the IRE $\alpha$-XBP1 branch of the unfolded protein response and counteracts endoplasmic reticulum stress-induced hepatic steatosis. J Biol Chem 289: 29751-29765. http://dx.doi.org/10.1074/jbc.M114.565960.

Jiang S, Zhang R, Li H, Fang Q, Jiang F, Hou X, Hu C, Jia W (2014) The single nucleotide polymorphism rs499765 is associated with fibroblast growth factor 21 and nonalcoholic fatty liver disease in Chinese population with normal glucose tolerance. J Nutrigenet $N u$ trigenomics 7: 121-129. http://dx.doi.org/10.1159/000367943.

Kadamatsu T, Tabata M, Oike Y (2011) Angiopoietin-like proteins:emerging targets for treatment of obesity and related metabolic diseases. FEBS J 278: 559-564. http://dx.doi.org/10.1111/j.17424658.2010.07979.x.

Kahraman A, Sowa JP, Schlattjan M, Sydor S, Pronadl M, Wree A, Beilfuss A, Kilicarslan A, Altinbas A, Bechmann LP, Syn WK, Gerken G, Canbay A (2013) Fetuin-A mRNA expression is elevated in NASH compared with NAFL patients. Clin Sci (Lond) 125: 391-400. http://dx.doi.org/10.1042/CS20120542.
Kantartzis K, Peter A, Machicao F, Machann J, Wagner S, Konigsrainer I, Konigsrainer A, Schick F, Fritsche A, Haring H-U, Stefan N (2009) Dissociation between fatty liver and insulin resistance in humans carrying a variant of the patatin-like phospholipase 3 gene. Diabetes 58: 2616-2623. http://dx.doi.org/10.2337/db09-0279.

Kavanagh K, Espeland MA, Sutton-Tyrrell K, Barinas-Mitchell E, El Khoudary SR, Wildman RP (2013) Liver fat and SHBG affect insulin resistance in midlife women: the study of women's health across the nation (SWAN). Obesity (Silver Spring) 21: 1031-1038. http://dx. doi.org/10.1002/oby.20077.

Khan MS, Knowles BB, Aden DP, Rosner W (1981) Secretion of testosterone-estradiol-binding globulin by a human hepatoma-derived cell line. J Clin Endocrinol Metab 53: 448-449. http://dx.doi. org/10.1210/jcem-53-2-448.

Kharitonenkov A, Beals JM, Micanovic R, Stifler BA, Rathnachalam R, Wroblewski VJ, Li S, Koester A, Ford AM, Coskun T, Dunbar JD, Cheng CC, Frye CC, Bumol TF, Moller DE (2013) Rational design of a fibroblast growth factor 21-based clinical candidate LY2405319. PLoS One 8: e58575. http://dx.doi.org/10.1371/journal.pone.0058575.

Kim SH, Kim KH, Kim H-K, Kim M-J, Back SH, Konishi M, Itoh N, Lee M-S (2015) Fibroblast growth factor 21 participates in adaptation to endoplasmic reticulum stress and attenuates obesity-induced hepatic metabolic stress. Diabetologia 58: 809-818. http://dx.doi. org/10.1007/s00125-014-3475-6.

Kitazawa M, Ohizumi Y, Oike Y, Hishinua T, Hashimoto S (2007) Angiopoietin-related growth factor suppresses gluconeogenesis through the Akt/Forkhead box class 01-dependent pathway in hepatocytes. J Pharmacol Exp Ther 323: 787-793. http://dx.doi.org/10.1124/ jpet.107.127530.

Kumashiro N, Erion DM, Zhang D, Kahn M, Beddow SA, Chu X, Still CD, Gerhard GS, Han X, Dziura J, Petersen KF, Samuel VT, Shulman G (2011) Cellular mechanism of insulin resistance in nonalcoholic fatty liver disease. Proc Natl Acad Sci USA 108: 1638116385. http://dx.doi.org/10.1073/pnas.1113359108.

Lan F, Misu H, Chikamoto K, Takayama H, Kikuchi A, Mohri K, Takata N, Hayashi H, Mutsazawa-Nagata N, Takeshita Y, Noda H, Matsumoto Y, Ota T, nagano T, Nakagen M, Miayamoto K, Takatsuki K, Seo T, Iwayama K, Tokuyama K, Matsugo S, Tang H, Saito Y, Yamoagoe S, Kaneko S, Takamura T (2014) LECT2 functions as a hepatokine that links obesity to skeletal muscle insulin resitance. Diabetes 63: 1649-1664. http://dx.doi.org/10.2337/db13-0728.

Lazo M, Zeb I, Nasir K, Tracy RP, Budoff MJ, Ouyang P, Vaidya D (2015) Association between endogenous sex hormones and liver fat in a multiethnic study of atherosclerosis. Clin Gastroenterol Hepatol 13: 1686-1693. http://dx.doi.org/10.1016/j.coh.2014.12.033.

Lebensztejn DM, Bialokoz-Kalinowska I, Klusek-Oksiuta M, Tarasow E, Wojtkowska M, Kaczmarski M (2014) Serum fetuin A concentration is elevated in children with non-alcoholic fatty liver disease. $A d v$ Med Sci 59: 81-84. http://dx.doi.org/10.1016/j.advms.2013.08.003.

Lebensztejn DM, Wasilewska N, Bobrus-Chociej A, Werpachowska I, Tarasow E (2016) Fibroblast growth factor 21 concentration in obese children with nonalcoholic fatty liver disease. Hepatol Int 10(suppl 1): 398-399 (abstract)..

Lee J, Hong SW, Park SE, Rhee EJ, Park CY, Oh KW, Park SW, Lee WY (2014) Exendin-4 regulates lipid metabolism and fibroblast growth factor-21 in hepatic steatosis. Metabolism 63: 1041-1048. http://dx.doi.org/10.1016/j.metabol.2014.04.011.

Li H, Dong K, Fang Q, Hou X, Zhou M, Bao Y, Xiang K, Xu A, Jia W (2013) High serum level of fibroblast growth factor 21 is an independent predictor of non-alcoholic fatty liver disease: a 3-year prospective study in China. I Hepatol 58: 557-563. http://dx.doi. org/10.1016/j.jhep.2012.10.029.

Li H, Fang Q, Gao F, Fan J, Zjou J, Wang X, Zhang H, Pan X, Bao Y, Xiang K, Xu A, Jia W (2010) Fibroblast growth factor $21 \mathrm{lev}$ els are increased in nonalcoholic fatty liver disease patients and are correlated with hepatic triglyceride. J Hepatol 53: 934-940. http:// dx.doi.org/10.1016/j.jhep.2010.05.018.

Li H, Zhang J, Jia W (2013) Fibroblast growth factor 21: a novel metabolic regulator from pharmacology to physiology. Front Med 7: 2530. http://dx.doi.org/10.1007/s11684-013-0244-8.

Li K, Li L, Yang M, Liu H, Boden G, Yang G (2012) The effects of fibroblast growth factor-21 knockdown and over-expression on its signaling pathway and glucose-lipid metabolism in vitro. Mol Cell Endocrinol 348: 21-26. http://dx.doi.org/10.1016/j.mce.2011.07.026.

Liu J, Xu Y, Hu Y, Wang G (2015) The role of fibroblast growth factor 21 in the pathogenesis of non-alcoholic fatty liver disease and implications for therapy. Metabolism 64: 380-390. http://dx.doi. org/10.1016/j.metabol.2014.11.009.

Malin SK, Mulya A, Fealy CE, Haus JM, Pagadala MR, Scelsi AR, Huang H, Flask CA, McCullough AJ, Kirwan JP (2013) Fetuin-A is linked to improved glucose tolerance after short-term exercise training in nonalcoholic fatty liver disease. J Appl Physiol 115: 988-994. http://dx.doi.org/10.1152/japplphysiol.00237.2013.

Mathews ST, Singh GP, Ranalletta M, Cintron VJ, Qiang X, Goustin AS, Jen KL, Charron MJ, Jahnen-Dechent W, Grunberger G 
(2002) Improved insulin sensitivity and resistance to weight gain in mice null for the Ahsg gene. Diabetes 51: 2450-2458. http://dx.doi. org/10.2337/diabetes.51.8.2450.

Misu H, Ishikura K, Kurita S, Takeshita Y, Ota T, Saito Y, Takahashi K, Kaneko S, Takamura T (2012) Inverse correlation between serum levels of selenoprotein $\mathrm{P}$ and adiponectin in patients with type 2 diabetes. PLoS One 7: e34952. http://dx.doi.org/10.1371/journal. pone.0034952.

Misu H, Takamura T, Takayama H, Hayashi H, Matsuzawa-Nagata N, Kurita S, Ishikura K, Ando H, Takeshita Y, Ota T, Sakurai M, Yamashita T, Mizukoshi E, Yamashita T, Honda M, Miyamoto K, Kubota T, Kubota N, Kadowaki T, Kim HJ, Lee IK, Minokoshi Y, Saito Y, Takahashi K, Yamada Y, Takakura N, Kaneko S (2010) A liver-derived secretory protein, selenoprotein $\mathrm{P}$, causes insulin resistance. Cell Metab 12: 483-495. http://dx.doi.org/10.1016/j. cmet.2010.09.015.

Mori K, Emoto M, Inaba M (2012) Fetuin A and the cardiovascular system. Adv Clin Chem 56: 175-195. http://dx.doi.org/10.1016/ B978-0-12-394317-0.00010-8.

Mori K, Emoto M, Inaba M (2011) Fetuin A: a multifunctional protein. Recent Pat Endocr Metab Immune Drug Discov 5: 124-146. http://dx.doi.org/10.2174/187221411799015372.

Mori K, Emoto M, Yokoyama H, Araki T, Teramura M, Koyama H, Shoji T, Inaba M, Nishizawa Y (2006) Association of serum fetuin-A with insulin resistance in type- 2 diabetic and nondiabetic subject. Diabetes Care 29: 468. http://dx.doi.org/10.2337/diacare.29.02.06.dc05-1484.

Mu J, Pinkstaff J, Li Z, Skidmore L, Li H, Myler H, Dallas-Yang Q, Putnam AM, Yao J, Bussell S, Wu M, Norman TC, Rodriquez CG, Kimmel B, Metzger JM, Manibusan A, Lee D, Zaller DM, Zhang BB, Dimarchi RD, Berger JP, Axelrod DW (2012) FGF21 analogs of sustained action enabled by orthogonal biosynthesis demonstrate enhanced antidiabetic pharmacology in rodents. Diabetes 61: 505512. http://dx.doi.org/10.2337/db11-0838.

Namkung J, Koh SB, Kong ID, Choi J-W, Yeh B-I (2011) Serum levels of angiopoietin-related growth factor are increased in metabolic syndrome. Metabolism 60: 564-568. http://dx.doi.org/10.1016/j.metabol.2010.05.013.

Nishimura T, Nakatake Y, Konishi M, Itoh N (2000) Identification of a novel FGF, FGF-21, preferentially expressed in the liver. Biochim Biophys Acta 1492: 203-206. http://dx.doi.org/10.1016/S01674781(00)00067-1.

Oike Y, Akao M, Yasunaga K, Yamauchi T, Morisada T, Ito Y, Urano T, Kimura Y, Kubota Y, Maekawa H, Miyamoto T, Miyata K, Matsumoto S, Sakai J, Nakagata N, Takeya M, Koseki H, Ogawa Y, Kadowaki T, Suda T (2005) Angiopoietin-related growth factor antagonized obesity and insulin resistance. Nat Med 11: 400-408. http://dx.doi.org/10.1038/nm1214.

Oike Y, Kasunaga K, Ito Y, Matsumoto S, Maekawa H, Morisada T, Arai F, Nakagata N, Takeya M, Masuho Y, Suda T (2003) Angiopoietin-related growth factor (AGF) promotes epidermal proliferation, remodeling and regeneration. Proc Natl Acad Sci USA 100: 9494-9499. http://dx.doi.org/10.1073/pnas.1531901100.

Okumura A, Unoki-Kubota H, Matsushita Y, Shiga T, Moriyoshi Y, Yamagoe S, Kaburagi Y (2013) Increased serum leukocyte cell-derived chemotaxin 2 (LECT2) in obesity and fatty liver. Biosi Trends 7: 276-283. http://dx.doi.org/10.5582/bst.2013.v7.6.276.

Oral EA, Simha V, Ruiz E, Andewelt A, Premkumar A, Snell P, Wagner AJ, DePaoli AM, Reitman ML, Taylor SI, Gorden P, Garg A (2002) Leptin-replacement therapy for lipodystrophy. N Engl J Med 346: 570-578. http://dx.doi.org/10.1056/NEJMoa012437.

Ou H-Y, Yang Y-C, Wu H-T, Wu J-S, Lu F-H, Chang C-J (2012) Increased fetuin-A concentration in impaired glucose tolerance with or without nonalcoholic fatty liver disease, but not impaired fasting glucose. J Clin Endocrinol Metab 97: 4717-4723. http://dx.doi. org/10.1210/jc.2012-2414.

Pacifico L, Nobili V, Anania C, Verdecchia P, Chiesa C (2011) Pediatric nonalcoholic fatty liver disease, metabolic syndrome and cardiovascular risk. World J Gastroenterol 17: 3082-3091. http://dx.doi. org/10.3748/wjg.v17.i26.3082

Pal D, Dasgupta S, Kundu R, Maitra S, Das G, Mukhopadhyay S, Ray S, Majumdar SS, Bhattacharya S (2012) Fetuin-A acts as an endogenous ligand of TLR4 to promote lipid-induced insulin resistance. Nat Med 18: 1279-1285. http://dx.doi.org/10.1038/nm.2851.

Parola M, Marra F (2011) Adipokines and redox signaling: impact on fatty liver disease. Antioxid Redox Signal 15: 461-483. http://dx.doi. org/10.1089/ars.2010.3848.

Pedersen KO (1944). Fetuin, a new globulin isolated from serum. $\mathrm{Na}$ ture 154: 575. http://dx.doi.org/10.1038/154575a0.

Perry RJ, Samuel VT, Petersen KF, Shulman GI (2014) The role of hepatic lipids in hepatic insulin resistance and type 2 diabetes. $\mathrm{Na}$ ture 510: 84-91. http://dx.doi.org/10.1038/nature13478.

Peter A, Kantartzis K, Machann J, Schick F, Staiger H, Machicao F, Schleicher E, Fritsche A, Haring H-U, Stefan N (2010) Relationship of circulation sex-hormone-binding globulin with metabolic traits in humans. Diabetes 59: 3167-3173. http://dx.doi.org/10.2337/db100179.

Peter A, Kantartzis K, Machicao F, Machann J, Wagner S, Templin S, Konigsrainer I, Konigsrainer A, Schick F, Fritsche A, Haring H-U, Stefan N (2012) Visceral obesity modulates the impact of apolipoprotein C3 gene variants on liver fat content. Int J Obes (Lond) 36: 774-782. http://dx.doi.org/10.1038/ijo.2011.154.

Petersen KF, Dufour S, Hariri A, Nelson-Williams C, Foo JN, Zhang XM, Dziura J, Lifton RP, Shulman GI (2010) Apolipoprotein C3 gene variants in nonalcoholic fatty liver disease. N Engl J Med 362: 1082-1089. http://dx.doi.org/10.1056/NEJMoa0907295.

Polyzos SA, Kountouras J, Tsatsoulis A, Zafeiriadou E, Katsiki E, Patsiaoura K, Zavos C, Anastasiadou VV, Slavakis A (2013) Sex steroids and sex hormone-binding globulin in postmenopausal women with nonalcoholic fatty liver disease. Hormones (Athens) 12: 405-416.

Raddatz K, Turner N, Frangioudakis G, Liao BM, Pedersen DJ, Cantley J, Wilks D, Preston E, Hegarty BD, Leitges M, Raftery MJ, Biden TJ, Schmitz-Peiffer C (2011) Time-dependent effect of Prkce deletion on glucose hemostasis and hepatic lipid metabolism on dietary liver oversupplay in mice. Diabetologia 54: 1447-1456. http:// dx.doi.org/10.1007/s00125-011-2073-0.

Reinehr T, Roth CL (2008) Fetuin A and its relations to metabolic syndrome and fatty liver disease in obese children before and after weight loss. J Clin Endocrinol Metab 93: 4479-4485. http://dx.doi. org/10.1210/jc.2008-1505.

Reinehr T, Woelfle J, Wunsch R, Roth CL (2012) Fibroblast growth factor 21 (FGF-21) and its relation to obesity, metabolic syndrome, and nonalcoholic fatty liver in children: a longitudinal analysis. $J$ Clin Endocrinol Metab 97: 2143-2150. http://dx.doi.org/10.1210/ jc.2012-1221.

Reschke S, Eckel J (2013) Adipo-myokines: two sides of the same coin - mediators of inflammation and mediators of exercise. Mediators Inflamm 2013: 320724. http://dx.doi.org/10.1155/2013/320724.

Roden (2006) Mechanisms of disease: hepatic steatosis in type 2 diabetes - pathogenesis and clinical relevance. Nat Clin Pract Endocrinol Metab 6: 335-348. http://dx.doi.org/10.1038/ncpendmet0190.

Romeo S, Kozlitina J, Xing C, Pertsemlidis A, Cox D, Pennacchio LA, Boerwinkle E, Cohen JC, Hobbs HH (2008) Genetic variation in PNPLA3 confers susceptibility to nonalcoholic fatty liver disease. Nat Gen 40: 1461-1465. http://dx.doi.org/10.1038/ng.257.

Roos M, von Eynatten M, Heemann U, Rothenbacher D, Brenner H, Breitling LP (2010) Serum fetuin A, cardiovascular risk factor, and six-year follow-up outcome in patients with coronary heart disease. Am J Cardiol 105: 1666-1672. http://dx.doi.org/10.1016/j.amjcard.2010.01.342.

Samuel VT, Liu ZX, Qu X, Elder BD, Bilz S, Befroy D, Romanelli AJ, Shulman GI (2004) Mechanism of hepatic insulin resistance in non-alcoholic fatty liver disease. J Biol Chem 279: 32345-32353. http://dx.doi.org/10.1074/ibc.M313478200

Sato M, Kamada Y, Takeda Y, Kida S, Ohara Y, Fujii H, Akita M, Mizutani K, Yoshida Y, Yamada M, Hougaku H, Takehara T, Miyoshi E (2015) Fetuin-A negatively correlates with liver and vascular fibrosis in nonalcoholic fatty liver disease subjects. Liver Int 35: 925-935. http://dx.doi.org/10.1111/liv.12478.

Shen J, Chan HL, Wong GL, Choi PC, Chan AW, Chan HY, Chim AM, Yeung DK, Chan FK, Woo J, Yu J, Chu WC, Wong VW (2012) Non-invasive diagnosis of non-alcoholic steatohepatitis by combined serum biomarkers. J Hepatol 56: 1363-1370. http:// dx.doi.org/10.1016/j.jhep.2011.12.025.

Shin JY, Kim S-K, Lee MY, Kim HS, Ye BI, Shin YG, Baik SK, Chung CH (2011) Serum sex hormone-binding globulin levels are independently associated with nonalcoholic fatty liver disease in people with type 2 diabetes. Diabetes Res Clin Pract 94: 156-162. http://dx.doi.org/10.1016/j.diabres.2011.07.029

Siddiq A, Lepretre F, Hercberg S, Froguel P, Gibson F (2005) A synonymous coding polymorphism in the $\alpha 2$-Heremans-Schmid glycoprotein gene is associated with type 2 diabetes in French Caucasian. Diabetes 54: 2477-2481. http://dx.doi.org/10.2337/diabetes.54.8.2477.

Simo R, Saez-Lopez C, Lecube A, Hernandez C, Fort JM, Selva DM (2014) Adiponectin upregulates SHGB production: molecular mechanisms and potential implication. Endocrinology 155: 2820-2830. http://dx.doi.org/10.1210/en.2014-1072.

Simo R, Saez-Lopez C, Lecube A, Hernandez C, Fort JM, Selva DM (2015) Novel insights in SHGB regulation and clinical Implication. Trends Endocrinol Metab 26: 376-383. http://dx.doi.org/10.1016/j. tem.2015.05.001.

Srinivas PR, Wagner AS, Reddy LU, Deutsch DD, Leon MA, Goustin AS, Grunberger G (1993) Serum $\alpha 2$-HS-glycoprotein is an inhibitor of the human insulin receptor at the tyrosine kinase level. Mol Endocrinol 7: 1445-1455. http://dx.doi.org/10.1210/mend.7.11.7906861.

Stefan N, Haring H-U (2013) The role of hepatokines in metabolism. Nat Rev Endocrinol 9: 144-152. http://dx.doi.org/10.1038/nrendo.2012.258. 
Stefan N, Haring H-U (2013) Circulating fetuin-A and free fatty acids interact to predict insulin resistance in humans. Nat Med 19: 394 395. http:/ /dx.doi.org/10.1038/nm.3116.

Stefan N, Hennige AM, Staiger H, Machann J, Schick F, Krober SM, Machicao F, Fritsche A, Haring H-U (2006) Alpha2-Heremans-Schmid glycoprotein/fetuin A is associated with insulin resistance and fat accumulation in the liver in humans. Diabetes Care 29: 853-857. http://dx.doi.org/10.2337/diacare.29.04.06.dc05-1938.

Stefan N, Kantartzis K, Haring H-U (2008) Causes and metabolic consequences of fatty liver. Endoor Rev 29: 939-960. http://dx.doi. org/10.1210/er.2008-0009.

Stefan N, Schick F, Haring H-U (2009) Sex hormone-binding globulin and risk of type 2 diabetes. N Eng J Med 361: 2675-2676. http:// dx.doi.org/10.1056/NEJMc0910143.

Stefan N, Schick F, Haring H-U (2014) Ectopic fat in insulin resistance, dyslipidemia, and cardiometabolic disease. $N$ End J Med 371: 2236-2237. http://dx.doi.org/10.1056/NEJMc 1412427\#SA3.

Stefan N, Sun Q, Fritsche A, Machann J, Schick F, Gerst F, Jeppesen C, Joost HG, Hu FB, Boeing H, Ullrich S, Häring HU, Schulze MB (2014) Impact of the adipokine adiponectin and the hepatokine fetuin-A on the development of type 2 diabetes: prospective cohort - and cross-sectional phenotyping studies. PLoS One 18: e92238. http://dx.doi.org/10.1371/journal.pone.0092238.

Sutton-Tyrrell K, Wildman RP, Matthews KA, Chae C, Lasley BL, Brockwell S, Pasternak RC, Lloyd-Jones D, Sowers MF, Torrens JL, SWAN investigators (2005) Sex-hormone-binding globulin and the free androgen index are related to cardiovascular risk factor in multiethnic premenopausal and perimenopausel women enrolled in the Study of Women Across the Nation (SWAN). Circulation 111: 12421249. http://dx.doi.org/10.1161/01.CIR.0000157697.54255.CE.

Takata H, Ikeda Y, Suehiro T, Ishibashi A, Inoue M, Kumon Y, Terada Y (2009) High glucose induces transactivation of the $\alpha 2-\mathrm{HS}$ glycoprotein gene through the ERK1/2 signaling pathway. $J$ Atheroscler Thromb 16: 448-456. http://dx.doi.org/10.5551/jat.No950 .

Tanaka N, Takahashi S, Zhang Y, Krausz KW, Smith PB, Patterson AD, Gonzalez FJ (2015) Role of fibroblast growth factor 21 in early stage of NASH induced by methionine- and choline-deficient diet. Biochim Biophys Acta 1852: 1242-1252. http://dx.doi.org/10.1016/j. bbadis.2015.02.012.

Targher G, Bertolini L, Poli F, Rodella S, Scala L, Tessari R, Zenari L, Falezza G (2005) Nonalcoholic fatty liver disease and risk of future cardiovascular events among type 2 diabetic patients. Diabetes 54: 3541-3546. http://dx.doi.org/10.2337/diabetes.54.12.3541.

Targher G, Day CP, Bonora E (2010) Risk of cardiovascular disease in patients with nonalcoholic fatty liver disease. N Eng J Med 363: 1341-1350. http://dx.doi.org/10.1056/NEJMra0912063.

Vernon G, Baranova A, Younossi ZM (2011) Systematic review: the epidemiology and natural history on non-alcoholic fatty liver disease and non-alcoholic steatohepatitis in adults. Aliment Pharmacol Ther 34: 274-285. http://dx.doi.org/10.1111/j.1365-2036.2011.04724.x.

Weikert C, Stefan N, Schulze MB, Pischon T, Berger K, Joost HG, Haring HU, Boeing H, Fritsche A (2008) Plasma fetuin-A levels and the risk of myocardial infarction and ischemic stroke. Circulation
118: 2555-2562. http://dx.doi.org/10.1161/CIRCULATIONAHA. 108.814418

Xu J, Lloyd DJ, Hale C. Stanislaus S, Chen M, Sivits G, Vonderfecht S, Hecht R, Li YS, Lindberg RA, Chen JL, Jung DY, Zhang Z, Ko HJ, Kim JK, Veniant MM (2009) Fibroblast growth factor 21 reverses hepatic steatosis, increases energy expenditure, and improves insulin sensitivity in diet-induced obese mice. Diabetes 58: 250-259. http://dx.doi.org/10.2337/db08-0392.

Yamagoe S, Yamakawa Y, Matsuo Y, Minowada J, Mizuno S, Suzuki K (1996) Purification and primary amino acid sequence of a novel neutrophil chemotactic factor LECT2. Immunol Lett 52: 9-13. http://dx.doi.org/10.1016/0165-2478(96)02572-2.

Yamagoe S, Mizuno S, Suzuki K (1998) Molecular cloning of human and bovine LECT2 having a neutrophil chemotactic activity and its specific expression in the liver. Biocbem Biophys Acta 1396: 105-113. http://dx.doi.org/10.1016/S0167-4781(97)00181-4.

Yan H, Xia M, Chang X, Xu Q, Bian H, Zeng M, Rao S, Yao X, Tu Y, Jia W, Gao X (2011) Circulating fibroblast growth factor 21 levels are closely associated with hepatic fat content. PLoS One 6: e24895. http://dx.doi.org/10.1371/journal.pone.0024895.

Yang SJ, Hwang SY, Choi HY, Yoo HJ, Seo JA, Kim SG, Kim NH, Baik SH, Choi DS, Choi KM (2011) Serum selenoprotein P levels in patients with type 2 diabetes and prediabetes: implications for insulin resistance, inflammation, and atherosclerosis. J Clin Endocrinol Metab 96: 1325-1329. http://dx.doi.org/10.1210/jc.2011-0620.

Yilmaz Y, Eren F, Yonal O, Kuty R, Altas B, Celikel CA, Ozdogan O, Imeryuz N, Kalayci C, Avsar E (2010) Increased serum FGF21 levels in patients with nonalcoholic fatty liver disease. Eur J Clin Invest 40: 887-892. http://dx.doi.org/10.1111/j.1365-2362.2010.02338.x.

Yilmaz Y, Yonal O, Kurt R, Ari F, Oral AY, Celikel CA, Korkmaz S, Ulukaya E, Ozdogan O, Imeryuz N, Avsar E, Kalayci C (2010) Serum fetuin $\mathrm{A} /$ alpha2HS-glycoprotein levels in patients with non-alcoholic fatty liver disease: relation with liver fibrosis. Ann Clin Biochem 47: 549-553. http://dx.doi.org/10.1258/acb.2010.010169.

Yoo HJ, Choi KM (2015) Hepatokines as a link between obesity and cardiovascular disease. Diabetes Metab J 39: 10-15. http://dx.doi. org/10.4093/dmj.2015.39.1.10.

Yu C, Chen Y, Cline GW, Zhang D, Zong H, Wang Y, Bergeron R, Kim JK, Cushman SW, Cooney GJ, Atcheson B, White MF, Kraegen EW, Shulman GI (2002) Mechanism by which fatty acids inhibit insulin activation of insulin receptor substrate-1 (IRS-1) - associated phosphatidylinositol 3-kinase activity in the muscle. J Biol Chem 277: 50230-50236. http://dx.doi.org/10.1074/jbc.M200958200.

Zhang Y, Lei T, Huang JF, Wang SB, Zhou LL, Yang ZQ, Chen XD (2011) The link between fibroblast growth factor 21 and sterol regulatory element binding protein 1c during lipogenesis in hepatocytes. Mol Cell Endocrinol 342: 41-47. http://dx.doi.org/10.1016/j. mce.2011.05.003.

Zhang Y, Lei T (2015) Fibroblast growth factor 21 analogs for treating metabolic disorders. Front Endocrinol (Laussanne) 8: 168. http:// dx.doi.org/10.3389/fendo.2015.00168. 